\title{
Critical Literature Review: Women as Entrepreneurs in United Arab Emirates
}

\author{
Jelena Zivkovic \\ Student Affairs Department, American University of Nigeria
}

\begin{abstract}
It is focused on internal trading and service activities that contribute little to the economic growth of the society that has been impressive. Rather it simply is supported by the growth that can be attributed primarily to oil revenues. Women have traditionally been a part of the Emirati entrepreneurial scene, but in the form of home based micro-enterprise. This small scale literature review determines the contribution that can be made by entrepreneurs and especially women entrepreneurs to the overall society.
\end{abstract}

Keywords: entrepreneurs, United Arab Emirates, women

\section{Introduction}

The history of the United Arab Emirates goes back to the nineteenth century when the United Kingdom reached an agreement with a group of Sheikhs to establish what was then called the Trucial States or Trucial Oman. In 1971 the present country was formed from six states or sheikdoms, Abu Zaby, 'Ajman, Al Fujayrah, Ash Shariqah, Dubayy, and Umm al Qaywayn and became the United Arab Emirates. The nation has a Gross Domestic Product (GDP) per capita that is on a par with Western nations and is politically and internationally moderate.

The topography of the country is rolling sand dunes and dessert wasteland with mountains in the East. Less than one per cent of the land area is arable. The only natural resources are oil and natural gas of which there are substantial reserves. The coastline, which is on the southern approaches of the Straits of Hormuz, was once known as the pirates' coast. The population is slightly less than 5 million and more than 75 per cent of this population is of "non-nationals". This population is young, about 30 years old, and is growing rapidly, about 3.8 per cent annually. A large part of the population is "South Asian," about 50 per cent. There are another 20 per cent plus of other Arab and Iranian heritage. It is clearly an Islamic country.

Literacy is low, under 80 percent. The official language is Arabic, but Persian, English, Hindi and Urdu are common. The government is interesting in that the seven individual emirates are still powerful, and only some powers have been relinquished to the federal government. There are no political parties in the country. There is a legislative branch of which half is elected and the other half appointed by the rulers of the seven emirates.

The president and vice president are elected to five-year terms without term limits. They appoint the prime minister and deputy prime minister. The legal system is based on a combination of Shari's law and civil courts. The UAE has not accepted International Court of Justice (IJC) compulsory jurisdiction. There is no suffrage of any sort (CIA World Factbook, 2010).

There is an Abu Dhabi Businesswomen Council that has a web site. On November 4, 2012, it published an article by Dr. Rawdha Abdullah Al-Muttawaa, Chairperson of the organization. In the article Dr. Al-Muttawaa claimed that the women of the UAE had indeed played a significant role. The value of the role was apparent in the enhancement of national economic activity and their participation in many spheres. In spite of the support of the late Sheikh Zayed Bin Sultan Al-Nahyan and Sheikha Fatima Bint Mubarak Al-Nahyan, Chairperson of the UAE General Women's Union, the result was neither, "... not completely up to our ambitions and not tangible enough to meet our requirements." The shortfall was attributed to the problem that, "...our national businesswomen have failed to get a lending hand that might activate their role and help them to play a really tangible role..."

The Abu Dhabi Businesswomen Council was created in 2002 with the objective of carrying out a national women's development strategy with the purpose of increasing their participation in the economic performance and affairs of the UAE. It claims that there are more than 3,000 businesswomen in the Emirates involved in all economic, business and service sectors of the economy. The council is also involved in providing training to prospective women entrepreneurs in an effort to, “....rehabilitate our national women and expand the range of their participation in several professional and business activities." Unfortunately, the site fails to provide any information on the actual activities or businesses of its claimed membership of 3,000 (AlMuttawaa, 2007). 
This project looks at the entrepreneurial opportunities and outlook for the United Arab Emirates with particular emphasis on the opportunities available to women. It examines the economic opportunity for entrepreneurs regardless of gender. Then the special problems faced by female entrepreneurs are examined in detail. Finally, the legal and social problems involved in an entrepreneurial start up under Shari'a law are examined. There are three basic problems that will be critically examined these are stated as such:

1. The economic opportunity for entrepreneurs regardless of gender

2. The special problems faced by female entrepreneurs

3. The legal and social problems involved in financing an entrepreneurial start up under Shari'a law.

Each will be examined and a conclusion reached regarding the opportunities for entrepreneurs in general and female entrepreneurs in particular. There are a number of legal and sociological questions regarding the Emirates as a business climate particularly for outsiders. There is obviously a great deal of wealth in the country, but much of it seems to be controlled by the sheiks of Dubai and Abu Dubai. That is not to say that there are not a number of wealth and successful businessmen in the Emirates; there are.

By western standards, the legal system is unsatisfactory. Not only is the combination of Shari's law with civil courts complex, administration and enforcement are not uniform and for non-citizens, even those from strong western nations enforcement may seem harsh and unreasonable. The British newspaper The Guardian in an article of October 16, 2008 raises the question concerning the legal system as it applies to non-Emirati citizens.

Following a widely publicized arrest of a couple for having sex on an Emirati beach, It details a list of relatively recent arrests of British citizens for acts that would be either totally legal in other societies or simply ignored as examples of questionable taste. A woman was arrested when traces of prescription painkillers were found in her urine after she was arrested for a passport irregularity. In another case, a youth worker was jailed for four years and pardoned after five months because a microscopic spec of cannabis was found on one of his shoes. The British Foreign Office warns that even the smallest amount of illegal drugs, such as the cannabis found on sole of the youth workers shoe, can lead to four years of imprisonment. The sheikdom also considers some over the counter prescription drugs as illegal. The Foreign office website offers the following bits of advice:

It is a punishable offence to drink or be drunk in public.

$>$ "Public displays of affection are frowned upon, and there have been several arrests for kissing in public. Sex outside of marriage is illegal cohabitation, adultery and homosexual behavior are also illegal."

$>$ If an unmarried woman gives birth in the UAE, the authorities may refuse to issue her with a birth certificate and she may even face arrest.

$>$ The importation of narcotics, pork products and pornographic books and material is also forbidden and the FCO warns visitors to the UAE that videos, books and magazines could be subject to scrutiny and may be censored. (Stewart, 2008)

Clearly, none of this is directly relevant to the entrepreneurial questions of this project, but it is evidence of a "police state" environment that must be considered in the context of the legal and social environment of the nation. From the standpoint of an entrepreneur, a well-defined legal system is important. In the UAE, for women entrepreneurs this is even more critical.

There is a final question that is key to the long-term development of the Emirates, but one that is the subject of another study far more extensive than this one. It is the question of developing business capabilities that will supplement and eventually replace the petrochemical industry in terms of exports. The Emirates have essentially no natural resources except petrochemicals. The population is roughly a quarter UAE citizens and the balance foreign workers. It does have some industries such as aluminum and cement that take advantage of the energy resources and shipbuilding and repair that are primarily related to the tanker trade. Just what entrepreneurial opportunities exist in this area is critically important to the long-term outlook for the Emirates, but the answers are unclear. This further implies that the entrepreneurial opportunities that do exist are primarily in local business such as personal service and small-scale retailing. This position is supported by the literature research that is included in the following section.

\section{Literature}

The structure of the literature review will be very simple. It will be organized into material to answer the same three basic question posed in the introduction.

There are three basic problems examined in this project. 
1. The economic opportunity for entrepreneurs regardless of sex

2. The special problems faced by female entrepreneurs

3. The legal and social problems involved in financing an entrepreneurial start up under Shari'a law.

These are the key questions that related to the opportunities for female entrepreneurs in the Emirates.

Because the dynamics of the region are in some respects changing rapidly, while the literature review is based on academic articles that may have been written several years ago important facets have been verified using current press material to assure that the relevant facts and statements made are still valid.

\section{Entrepreneurial Opportunity}

There is an effort to promote entrepreneurial activity in the UAE. It is given lip service, but on a practical level, it has so far been insignificant. The other element in the question is what sort of entrepreneurial activity is being carried out. A very serious and professional study was completed in 2006, "A STUDY OF ENTREPRENEURSHIP IN THE UNITED ARAB EMIRATES 2006" written by Kenneth Press and Declan McGowan of Zayed University. The study focuses on ten dominant themes relevant to the level of overall entrepreneurial opportunity in the Emirates.

1. The UAE does not compare well relative to other emerging nations. It ranks close to the bottom both in terms of the number of startups and the number of young businesses that are functioning.

2. One of the primary problems is a very strong cultural significance fear of failure. This results in a high societal level risk aversion.

3. The study finds that the educational level of the entrepreneur is a critical element in the chance for success. The study finds that non-degree education providing practical skills is actually more effective in terms of entrepreneurial success, but does not address the fear of failure referred to above. An educational degree seems to lower the fear factor more effectively.

4. Most UEA entrepreneurs depend on their own funds or family funds for start up capital. There is also a religious/societal prohibition against bank or any borrowing at interest that will be discussed below. Public or private venture capital investors are virtually non-existent in the Emirates.

5. The study finds that propensity to start a new venture is much lower among women.

6. At the time the study was conducted, 2005-6, there was general enthusiasm for the level of opportunity in the immediate future. This was offset by the fear of failure and the lack of confidence of the respondents in their level of required skills for success.

7. There was a strong feeling that business success enhanced the social perception of the successful entrepreneur. It was therefore viewed as a positive career path. This was viewed as a strong positive in the situation.

8. The existing UAE business community is providing conventional products and services to their local customers. It is important that new entrepreneurs focus on nascent businesses and emerging technology.

9. At the time the study was being prepared, about two years ago, business start up intentions in the immediate future were relatively low compared to global expectations. Conversely, longer-term expectations were well above global standards. It would be interesting to make similar comparisons today. Even after the fall in global oil prices, the Emirates are still financially strong. What would the comparisons be today?

10. Entrepreneurship is a young peoples' world. It is far more common for younger people to become entrepreneurs than middle age or older prospects.

This indicates that the environment for entrepreneurs in the Emirates, while far from negative is difficult. The study is focused on citizens of the country. Emirate citizens who are employed are in large part government employees, and are risk adverse and satisfied with the general well-paid and undemanding life of the UAE government employee.

When this is combined with the difficulty of developing a viable concept for a large scale business which would imply some export or international potential and the difficulty in raising financing the overall outlook for the potential entrepreneur is bleak (Preiss \& McCrohan, 2006).

A study by Hans Haan for The National Human Resource Development and Employment Authority, "Small Enterprise: Women Entrepreneurs in the UAE" looks more specifically at the situation for women in the Emirates. There are two distinct segments in the women managed small enterprise (WSE) sector in the UAE:

(i) Traditional activities consisting mostly of trading and simple manufacturing (e.g. perfume mixing, 
traditional cloth-making and various handicrafts), which are carried out in WSEs headed by relatively elderly, modestly educated women entrepreneurs who operate from their homes, and

(ii) Modern activities that refer to small businesses engaged in economic activities of more recent origin, often making ample use of advanced information and communication techniques and up-to-date business practices, managed mostly by young, well-educated and more business-oriented UAE women entrepreneurs.

These are obviously unrelated except in the sense that they are businesses operated by women. While in no way denigrating the value of the traditional activities this study looks are the "modern activities" segment as being of primary interest. This is the segment that can make substantial contribution to the development of alternatives to oil based activities as economic drivers.

It must be mentioned that the study found a sub-segment of micro-businesses, mostly home based, that were operated by relatively young and well-educated women.

Many of these women had received at least some training in business management and skills and had several years of prior experience in business or government positions. These modest businesses were engaged primarily in trading or services, but several were small scale manufacturing operations of unspecified products. While they generally had small initial capital investment and sales, as a group they showed distinct potential for growth. Most of these businesses were part time activities, where the owner retained a conventional job. Only one in four of the women included in the study worked more than 30 hours per week in the business, and $40 \%$ worked no more than 10 hours per week in the business. This would indicate that most of the entrepreneurial activities were very marginal. The business was a hobby for fully $24 \%$ of the respondents in the study.

Of the respondents in the study, most indicated that they received family support. The respondents were active entrepreneurs at some level. This is not typical of the entire Emirate culture as there are strong cultural taboos concerned with women dealing with men to whom they are not related or simply being active outside the home. The respondents indicated that they are probably not typical.

The definition of entrepreneur included any sort of business. For example, within the study definitions, manufacturing generally involved tailoring of traditional clothing and weaving. Others were involved in personal services such as beauty shops. Capital investment for most of the businesses included in the study averaged about $£ 12,000$. A few required considerably larger investments. About $60 \%$ of the businesses were financed primarily by the funds of the entrepreneur.

More than half of the clientele of the businesses included in the survey were UAE nationals from the middle to high-income groups. About $21 \%$ were expatriates living in the Emirates and another $19 \%$ were from lower income strata. Most of the businesses did little promotion and counted on family, friends and word of mouth to garner new clients.

Typically, competition was from similar small firms as opposed to larger firms. Within the small segment engaged in "modern small businesses the difficulties included:

1) Lack of access to capital,

2) Inadequate entrepreneurial capabilities and lack of business experience,

3) Difficulties with some formal procedures,

4) Low levels of support from husbands and family in a number of cases

5) Demand and marketing difficulties

A common problem for all entrepreneurs in the UAE is lack of access to credit and capital. For women this is a still greater problem. According to the study, there is a paradox. "Women who have capital are usually not interested in starting a business, while women who are in need of an extra income do not know how to get the investment capital"'.

There are some limited support organizations for entrepreneurs and specifically women entrepreneurs, but they have limited capabilities. A businesswomen's council has formed, but it has enjoyed only limited success. One of the areas the study suggest as open to women who wish to become entrepreneurs in the modern as opposed to the traditional segment is the e-services sector. This requires education, computer literacy and language skills, but is suitable for operation from home and requires relatively modest initial capital investment. The development of e-service would also contribute towards UAE aspirations in this area (Haan, 2004). 


\section{Women's Rights In The Uae: The Special Problems Faced By Female Entrepreneurs}

In Their book, “Women's rights in the Middle East and North Africa”, Sameena Nazir, Leigh Tomppert examine the political and social implications of UAE society. They point out that there are no political parties in the Emirates and right of assembly is limited.

Non-Governmental organizations (NGO's) must register with the government and are subject to closure. There are no labor unions and foreign nationals, who comprise the bulk of the labor force, are not offered any forms of labor protection.

While in 2002, the Dubai police force created a human rights department to monitor prison conditions, rehabilitate prisoners, and conduct programs for crime victims. The UAE however allows no independent or external human rights organizations to function with the Emirates.

The rights of women are not specified in the UAE constitution, and in practice women's social, economic and legal rights are not consistently observed. There are traditional societal bias against women, and incomplete and selective implementation and enforcement of the existing law. The lives of women in the UAE and the laws that govern them vary dramatically depending on their citizenship, social status and employment status. The determinants are UAE citizenship, a foreign woman residing temporarily in the UAE on an employment contract, a foreign woman employed in an "informal" sector such as domestic employment, and the wife of a temporary foreign worker.

There are obviously considerable gaps the experiences of women in the UAE, their legal protections, and their ability to exercise such right as may be granted to them. To compound the situation, a substantial proportion of the women in the UAE remain uninformed of the rights and protections that are presumably available to them.

Islamic teachings are the basis of women's conditions, and there are some women's Koran study groups, but these tend to hold closely to the traditional views of Islamic teachings and reinforce the traditional subservient position of women in society under Islam. The movement of women is also restricted in spite of contrary provisions in the legal system. A man may prevent his wife, children, and unmarried females in his household from leaving the country by withholding their passports and contacting the authorities. It is also common practice for employers to hold the passports of foreign workers as a condition of employment.

This obviously makes it very difficult for the employees to terminate their employment, travel or even return to their home countries if they are not satisfied with their employment. This behavior persists in spite of a 2003 ban by the ministry of the interior. Many companies and employers continue the practice.

Within the family, Shari'a law continues to govern as specified in the personal status code. There is however, a duality of legal practice in Dubai in based on an option of pursuing domestic matters in a special Shi's council rather than through the courts. A Muslim man under Shari'a law and in the UAE may verbally divorce his wife. A woman can only be granted a divorce by a court of law, and only if the judge agrees that the husband has inflicted physical or emotional harm, abandoned her for more than three months or failed to provide for her and her children. Female domestic worker have virtually no right and are often abused. They also suffer from a law enforcement system that has little sympathy, and they may be imprisoned for complaining of ill treatment.

The economic rights for women are also less than equal. A woman may own land and property when they reach the age of 18 and they commonly exercise this right. On marriage, the husband has no rights to the property of the wife and she continues to own it in her own right. For an unmarried woman however, the law does not protect her property from her father or brothers. A male UAE citizen receives generous housing benefits while none are offered to women as it is assumed that they will share a home with their husband.

Inheritance law is in accordance with the UAE interpretation of Shari'a, which provides an unequal distribution of the assets of the deceased between male and female survivors for Muslims. For followers of other faiths distribution is based on religion.

Women who are UAE citizens have the right to license businesses in their own names, and conduct and manage the business. There are wide varieties of business that are owned and conducted by women. There is however, a serious problem in that it is not considered respectable for women to interact with men that are not husband or relative.

This results in many women being prevented from entering into business by husbands or male relatives.

UAE law concerning women is a dichotomy of various viewpoints according to the authors. They point to numerous examples such as maternity leave that is generous by most standards and even makes allowance for working mothers to nurse their babies on paid time. Women cannot be fired or threatened based on pregnancy. 
This is a very contemporary approach to women's rights and in stark contrast to much of the other discussion in this section (Nazir \& Tomppert, 2005).

The overall picture is one of an Islamic society firmly rooted in the past. The socio-political system is a conflicting combination of a dictatorial monarchy administered by some very intelligent and capable people and contemporary progressiveness. The picture painted for Emirati women is mixed with married women have some rights and single women almost none. The situation for non-citizens is still less benign. Some foreign workers are the equivalent of indentured servants or almost slaves. Emirati citizens make up a small part of the population and most "work" is done by immigrants.

\section{The Legal And Social Problems Involved In Developing And Financing An Entrepreneurial Start Up Under Shari'a Law}

The subject of women's rights is covered above. Islam is a patriarchal society, and women while revered and protected are in western eyes still second-class citizens.

The control granted to men over the activities of women is a hurdle that many Emirati women cannot overcome. Short of a social, cultural, religious, and legal overhaul of the nation there seems little chance that this will change dramatically. An interesting example of the problem and potential solution can be seen in the Shari'a Banking system. The Muslim scholar Sheikh Yusuf Al-Qaradawi approaches the question of bank interest as follows. "The interest on bank accounts is unlawful or haram (unlawful) because such interest is an increase of money made without effort or trade. Allah says, "O you who believe! Fear Allah and give up what remains of your demand for usury if you are indeed believers.

If you don't, take notice of war from Allah and His messenger. But if you turn back, you shall have your capital sums. Deal not unjustly and you shall not be dealt with unjustly." The underlying rule is that a devout Muslim cannot pay or accept interest. That is clear. This also means that the typical entrepreneur is barred from seeking or accepting "venture capital" because the venture capitalist indeed expects a return on his investment, usually a rather generous one. This is clearly a major problem in the entire question of UAE entrepreneurship.

What is truly interesting is the ingenuity of the Islamic community in getting around this little problem. Even 1400-year-old law can be adapted to modern needs by clever legal minds. Here is the approach of one UK Bank to the problem of granting mortgages that comply with Shari'a law. Lloyd's became the third UK bank to offer mortgage services compatible with Shari'a. What the bank does is purchase the property on behalf of the customer and then leasing it back to them in a way which allows them to legally own it at the same time, to get ownership." Therefore, the type of investment allowed is where a person deposits money in an account and shares both the risk of making profit or losing. The British bank would fund up to 90 percent of a house purchase and the customer would then repay that sum over a fixed period, alongside a rent payment for use of the property. Under the new mortgage, the amount paid over the 25 -year term would be broadly similar to a conventional mortgage.

An alternative would allow the bank to purchase the home outright and then sell it to the Islamic purchaser at an increase price payable over time, say 25 years with the profit built in to the price paid by the Islamic purchaser. Again there is no interest involved and the bank, not being Islamic, can make a profit on the purchase and sale transaction. As this could be considered a form of trading, it would be entitled to the profit. (IslamOnline.net, 2005)

It is considered haram to borrow at interest to start a business. At the same time, the legal ingenuity that permits a mortgage to be drawn under Shari'a should also permit loans for a business if that is the objective. It is clear that for a western venture capitalist or business to work under such a foreign legal system would require a substantial effort. At the same time, if the desire on both sides was sufficient, it should be possible for an entrepreneur to operate under the law.

\section{Research Methodology}

Conducting meaningful qualitative or quantitative research on the ground in the United Arab Emirates is outside the capability of this project. This is not serious because as indicted above in the literature section a wealth of material is available that was conducted with plentiful resources available by competent researchers. It must be recognized however that this material was prepared within the Emirates and as such had to be politically acceptable to the powers conducting the affairs of the country. This project can interpret their findings without fear or prejudice, and can thereby make a valid intellectual contribution to the problem. 


\section{Findings And Discussions: The Economic Opportunities For Entrepreneurs}

There are several special problems facing potential entrepreneurs in the UAE. These are in addition to the basic challenge of entrepreneurship. The first is the legal sociological situation in the Emirates. To be a successful entrepreneur other than as the proprietor of a micro-business is extremely difficult for anyone but an Emirate citizen. This is not to say it is impossible because enforcement of law and regulation seems to vary somewhat from one situation to another.

The basic environment for entrepreneurs is difficult as there are only limited opportunities for manufacture except on a small scale. The opportunities for technology-based businesses, especially Internet based businesses, are good and there seems to be a substantial pool of available young and well-trained talent. The limiting factor here is the ability of entrepreneurs worldwide to come up with viable original ideas. There are obviously a large number of Internet start-ups or expansion occurring even now after the end of the dotcom bubble. The successful ones are a tiny fraction of the number initiated. This is a general observation as opposed to anything particular to the Emirates.

The advantage and disadvantage of the Internet business is that it can be initiated anywhere there is an Internet connection available.

There are two serious problems in terms of entrepreneurial activity even for the Emeriti citizen. The first is the societal fear of failure that is the offset to the perception of prestige in developing and heading a successful enterprise. There is a societal bias toward conservatism that leads many Emeriti citizens into government employment as opposed to the business sector. The concept of "loss of face" involved in failure is similar in many respects to the Japanese culture's "face" obsession. Based on studies the enthusiasm for the concept of entrepreneurship is high among the young, but the realities of the possibility of failure discourage wide adoption of the concept.

The second major obstacle to a wider entrepreneurial effort is the difficulty in raising funding for new business. Simply put, in spite of the wealth of the oil rich nation there is a dearth of venture capital. This can be attributed in part to the inherent conservatism of the culture and in part to the religious and societal prohibition of investing for profit. Because of the legal environment, external venture capital is scarce. As a result, those entrepreneurs that do start businesses general are self or family funded. Only about a third get any external financing.

Most of the entrepreneurial activity that does exist is in the form of inherently small businesses; retail trade, restaurants and personal care establishments are examples. This has the drawback of adding little real wealth and growth to the economy. The overall economy has been growing well, and there is room in the market for these new small enterprises, but they are not drivers of growth but beneficiaries of the growth that results from other activities.

\section{The Situation For Female Entrepreneurs}

In terms of women entrepreneurs everything said above applies even more strongly. The problems of external finance and the societal prohibitions and taboos are even stronger for women that for the overall business community. The legal status of women is inferior.

Married women can own and operate businesses, but effectively, they must have the permission of their husbands to do so. If they are unmarried, their possessions and money are subject to seizure by male family members such a fathers, brothers and uncles. There are also prohibitions for women regarding any dealing with men to whom they are not related. Clearly, there are ways of dealing with this in the society nor is the entire Emeriti society strictly observant of Islamic tradition. While these problems may be less onerous than they would seem at first glance, they are very real problems in many cases.

There is one exception to many of the statements above in that there is a long tradition of women being the proprietors of micro enterprises such as tailoring of traditional garments, weaving and personal care and services establishments. Many of the so-called female entrepreneurs are actually involved in just such activities. It is also common for female entrepreneurs to operate their businesses from their homes on a part time basis to enable them to fulfil their responsibilities as wives and mothers. Of the statistics involving female entrepreneurs, few are full time. Many consider their business as hobbies as opposed to income generating activities. This sort of entrepreneurship does little for the UAE economy.

\section{VIIII. Summary And Conclusions}

The United Arab Emirates is a wealthy nation with substantial internal societal problems and an international image concerning human rights that is a negative. Based on the oil wealth of the UAE, and particularly that of Abu Dhabi, there is a tremendous financial resource base in the nation. This can serve as an 
offset to its lack of resources other than petrochemicals and offers the possibility of a continuation of the prosperity of the country as its oil reserves are consumed. Those of Dhabi are estimated to last for twenty years of less. Those of Abu Dhabi will last considerably longer, but are ultimately finite. It is therefore incumbent on the leadership of the nation to take steps to diversify its activities and that is why the subject of this project is important.

In order to achieve the diversification of its economy entrepreneurial activity must be fostered and the social constraints lifted to encourage external development in businesses within the national as well as nationalistic development of non-oil related activities. To this end, a considerable amount of change must be fostered in the legal and social structure. The present environment for entrepreneurship in the Emirates is not particularly positive. The barriers to women are even higher and more daunting than the entrepreneurial barriers for men. The barriers for non-citizens are truly daunting.

The Emirates must foster change in its legal structure, banking environment and society to facilitate progress. There are signs that some such progress has already been made, but further progress is absolutely necessary if the nation is not to suffer in the latter half of the $21^{\text {st }}$ century and beyond. It has invested vast sums in incredible real property development and has launched impressive promotional campaigns, but these will not be effective without social and legal progress to support them.

\section{References}

[1]. CIA World Factbook. (2010). United Arab Emirates. Retrieved October 24, 2008, from https://www.cia.gov/library/publications/theworld-factbook/index.htm

[2]. Al-Muttawaa, R. A. (2007). Main Page. Retrieved November 1, 2008, from http://www.adbusinesswomen.ae/index.htm

[3]. Stewart, E. (2008, October 16). Britons who have fallen foul of the law in Dubai. The Guardian. Retrieved October 23, 2008 from http://www.guardian.co.uk/world/2008/oct/16/4

[4]. Preiss, K., \& McCrohan, D. (2006). A Study Of Entrepreneurship in the United Arab Emirates 2006. Mohammed Bin Rashid Establishment and GEM United Arab Emirates. Retrieved November 2, 2008, from http://www.sme.ae/pdf/UAE_GEM_BOOK.pdf

[5]. Haan, H. C. (2004). Small Enterprises: Women Entrepreneurs in the UAE. In Dubai: Centre for Labour Market Research \& Information.

[6]. Nazir, S., \& Tomppert, L. (2005). Women's Rights in the Middle East and North Africa: Citizenship and Justice. Lanham MD: Rowman \& Littlefield.

[7]. Islamonline.Net. (2005, March 22). British Bank Launches Islamic Mortgage. Retrieved November 2, 2008, from http://www.islamonline.net/English/News/2005-03/22/article03.shtml 